\title{
Serapan Hara N, P, K dan Hasil Biji Kedelai (Glycine max L. Merrill) pada Pemberian Bokashi Pelepah Pisang pada Tanah Pasir Pantai
}

\section{Nutrient uptake of N, P, K and Soybean Seed Yield by Application of Bokashi made from Banana Stem in the Coastal Sandy Soils}

\author{
Khavid Faozi ${ }^{1 *}$, Prapto Yudono², Didik Indradewa², Azwar Ma'as ${ }^{3}$ \\ 1Jurusan Agroteknologi, Fakultas Pertanian, Universitas Jenderal Soedirman \\ ${ }^{2}$ Departemen Budidaya Pertanian, Fakultas Pertanian, Universitas Gadjah Mada \\ ${ }^{3}$ Departemen Tanah, Fakultas Pertanian, Universitas Gadjah Mada, Yogyakarta. \\ *) Penulis untuk korespondensi Email: khavid.faozi@unsoed.ac.id
}

\begin{abstract}
The ability of several soybean cultivars to absorb nutrient nitrogen, phosphorus, and potassium (NPK) may be different in the new growing environment in coastal sandy soils which are treated with bokashi made from banana stem. The aim of this study was to determine the NPK nutrient uptake and the responses of several soybean varieties to the level of banana stem bokashi application in coastal sandy soils, and to determine the optimum dose based on yield of soybean seeds. The research was a field experiment conducted for 4 months from January until April 2017. Pot experiments in the field have been done in Samas coastal sandy soils, Srigading Village, Sanden Sub-district, Bantul Regency, Special Region of Yogyakarta. The factorial experiment (4x12) was repeated 3 times, arranged in a complete randomized block design (RCBD). The first factor was dose banana stem bokashi including 0, 20, 40, and 60 t. ha ${ }^{-1}$ was tested on 12 soybean cultivars namely Anjasmoro, Argomulyo, Burangrang, Demas 1, Dena 1, Devon 1, Gamasugen 1, Gema, Gepak ljo, Grobogan, Kaba and Slamet. The observational data were analyzed by the variant analysis of the error rate of $5 \%$ and if significantly different was followed by DMRT 5\% error level. The results showed that bokashi made from banana stem can be used as a soil amandment for coastal sands soil, as well as providing nutrients for the growth of soybean plants. Nutrient uptake of $N, P, K$, plant dry weight, and seed yields of Anjasmoro cultivars, Argomulyo, Demas 1, Devon 1, Gepak ljo, Kaba and Slamet increased with the application of banana stem bokashi at doses of 20 and 40 t.ha $^{-1}$, and decreases at bokashi doses reaching 60 t.ha $^{-1}$. The optimum dose of bokashi made from banana stem doses equals 35.80 t.ha $^{-1}$ with a maximum seed yield of 22.24 g.pot ${ }^{-1}$.
\end{abstract}

Keywords: soybean; bokashi made from banana stem; coastal sandy soils; nutrient uptake of NPK

\section{INTISARI}

Kemampuan beberapa kultivar kedelai dalam menyerap hara nitrogen, fosfor, dan kalium (NPK) boleh jadi berbeda pada lingkungan tumbuh baru pada tanah pasir pantai yang diberi perlakuan bokashi pelepah pisang. Penelitian bertujuan untuk mengetahui serapan hara NPK dan tanggapan beberapa kultivar kedelai terhadap taraf pemberian bokashi pelepah pisang pada tanah pasir pantai, serta menentukan takaran optimumnya berdasarkan hasil bijinya. Penelitian telah dilakukan pada tanah pasir 
pantai Samas, desa Srigading, kecamatan Sanden, kabupaten Bantul, Daerah Istimewa Yogyakarta. Waktu penelitian selama 4 bulan, mulai Januari sampai dengan April 2017. Percobaan pot (polibeg) dengan rancangan perlakuan faktorial (4x12) disusun dengan Rancangan Acak Kelompok Lengkap (RAKL), dan diulang 3 (tiga) kali. Faktor pertama yaitu dosis bokashi meliputi: 0, 20, 40 dan 60 t.ha $^{-1}$ dan faktor kedua adalah kultivar kedelai yaitu Anjasmoro, Argomulyo, Burangrang, Demas 1, Dena 1, Devon 1, Gamasugen 1, Gema, Gepak ljo, Grobogan, Kaba, dan Slamet. Data pengamatan dianalisis varian (anova) dan bila berbeda nyata dilanjutkan dengan DMRT taraf kesalahan 5\%. Hasil penelitian menunjukkan bokashi pelepah pisang dapat digunakan sebagai pembenah tanah pasir pantai, sekaligus sebagai penyedia unsur hara bagi pertumbuhan tanaman kedelai. Serapan hara N, P, K, bobot kering tanaman, dan hasil biji kultivar Anjasmoro, Argomulyo, Demas 1, Devon 1, Gepak ljo, Kaba dan Slamet meningkat dengan pemberian bokashi pelepah pisang pada takaran 20 dan 40 t.ha $^{-1}$, dan menurun pada takaran bokashi mencapai 60 t.ha ${ }^{-1}$. Dosis optimum takaran bokashi pelepah pisang setara 35,80 t.ha $^{-1}$ dengan hasil biji maksimum 22.24 g.pot ${ }^{-1}$.

Kata kunci: kedelai; bokashi pelepah pisang; lahan pasir pantai; serapan NPK

\section{PENDAHULUAN}

Pantai berpasir yang terletak di wilayah selatan Daerah Istimewa Yogyakarta (DIY) dan Jawa Tengah tepatnya bagian selatan kabupaten Bantul hingga kabupaten Cilacap merupakan lahan pasir yang memiliki potensi untuk dikembangkan menjadi lahan budidaya pertanian, termasuk kedelai. Menurut Hani (2015) kultivar kedelai Dena 2 produktivitasnya mencapai 2,37 ton.ha $^{-1}$ pada pola agroforestri Nyamplung (Callophylum inophylum L.) di lahan pasir pantai Pengandaran. Pemanfaatan lahan pasir pantai Samas di kabupaten Bantul Daerah Istimewa Yogyakarta (DIY) bahkan sudah dimulai sejak tahun 1986 yaitu untuk budidaya tanaman hortikultura (Partoyo, 2005). Namun demikian, lahan pasir pantai memiliki kendala utama yaitu ketersediaan hara yang rendah baik hara makro maupun hara mikro (Syukur and Harsono, 2008) juga kemampuan menyimpan hara yang rendah (Hall and Bell, 2015).

Guna menunjang keberhasilan budidaya kedelai di lahan pasir pantai, selain dengan menggunakan kultivar (genotip) kedelai yang adaptif, juga memerlukan masukan berupa bahan organik. Salah satu sumber bahan organik yang melimpah dan belum banyak dimanfaatkan adalah pelepah pisang. Indonesia merupakan penghasil buah pisang terbesar di Asia Tenggara (Kementan, 2014) dengan rata-rata produksi 5 tahun terakhir 6,5 juta ton.tahun ${ }^{-1}$. Produksi pisang tahun 2015 bahkan mencapai 7,3 juta ton (Kementan, 2016). Apabila produksi pelepah pisang yang mencapai 2 kali produksi buah pisang (Munadjim, 1983) maka potensi ketersediaan pelepah pisang mencapai lebih dari 14 juta ton (berat segar) setiap tahunnya. Menurut Pezo and 
Fanola (1980) cit Wina (2001) kadar air pelepah pisang berkisar antara 90.2-96.4\%, sehingga bahan kering yang dihasilkan dari pelepah pisang sebesar 0,5-1,4 juta ton.tahun ${ }^{-1}$. Ketersediaan pelepah pisang tersebut perlu dimanfaatkan sebagai bahan baku dalam pembuatan bokashi (kompos) untuk meningkatkan produktivitas tanah dan tanaman.

Pelepah pisang merupakan bahan yang berpotensi sebagai bahan baku bokashi, karena mengandung C (21.85\%), N (0.28\%), P (0.98 \%), K (3.30\%) dan C/N (78) (Iskak et al., 2014). Melalui pengomposan menggunakan EM4 selama 3 minggu akan diperoleh bokashi dengan komposisi kadar hara NPK $\left(0.94 \% \mathrm{~N} ; 1.45 \% \mathrm{P}_{2} \mathrm{O}_{5}\right.$; dan $1.81 \% \mathrm{~K}_{2} \mathrm{O}$ ) yang sudah memenuhi standar SNI 19-7030-2004 dan memiliki rasio $\mathrm{C} / \mathrm{N}$ (21) yang sudah memenuhi standar kualitas pupuk organik menurut peraturan mentan No.2/pert/HK.060/2/2006 (10-25). Menurut Kusumawati (2015) bokashi berbahan baku pelepah pisang usia 2 bulan mengandung C-organik (29.7\%), C/N rasio (17.8\%), $\mathrm{pH} \mathrm{H} \mathrm{H}_{2} \mathrm{O}$ (5.64), NPK total (7.74\%) sudah memenuhi syarat sebagai pupuk organik. Menurut Okelana (2001), kandungan unsur P, Na dan Mg pada pelepah pisang berkisar 0.1-0.3 \%, Ca 0.4-0.8 \%, K 5.5-6.2 \% dan abu 14-30 \%. Berdasarkan kandungan mineral dan abu tersebut, pelepah pisang juga dapat digunakan sebagai mulsa organik.

Berdasarkan kendala fisika, kimia, maupun biologi tanah pasir pantai, maka bokashi pelepah pisang diharapkan dapat berperan sebagai pembenah tanah, sekaligus sebagai penyedia hara untuk meningkatkan produktivitasnya terutama pada budidaya kedelai. Menurut Faozi (2018) total hara N, P dan K pada media tanah pasir meningkat dengan meningkatnya takaran bokashi pelepah pisang yang diberikan. Namun, kemampuan kultivar kedelai dalam menyerap unsur hara tersebut pada lingkungan tumbuh baru di lahan pasir pantai serta kaitannya dengan produksi bahan kering tanaman dapat lebih menjelaskan kesesuaian kultivar yang akan dikembangkan pada lingkungan tumbuhnya. Pemupukan N, P dan K menggunakan Urea, SP36, dan $\mathrm{KCl}$ efektif meningkatkan serapan hara $\mathrm{N}, \mathrm{P}$ dan $\mathrm{K}$ pada tanaman kedelai yang tumbuh di antara tegakan kayu putih (Jati et al., 2017).

Potensi hasil biji kultivar kedelai di lapangan dipengaruhi oleh interaksi antara faktor genetik dengan pengelolaan lingkungan tumbuhnya (Adie et al., 2015). Introduksi beberapa kultivar kedelai pada lingkungan tumbuh baru penting dilakukan untuk melihat daya adaptasinya. Sifat tanaman kedelai yang mampu menambat $\mathrm{N}_{2}$ di udara bebas, merupakan hal yang penting dalam menunjang keberhasilan pengembangan kedelai di lahan pasir pantai. Salvagiotti et al. (2008) mengemukakan 
sekitar 50-60\% kebutuhan $\mathrm{N}$ pada tanaman kedelai dapat terpenuhi melalui penambatan $\mathrm{N}_{2}$ secara biologi pada berbagai tingkatan hasil dan lingkungan tumbuh. Kenyataannya tidak semua rhizobium yang mampu membentuk bintil akar efektif untuk tanaman kedelai (Purwaningsih, 2015). Ketersediaan hara N, P dan K pada media tanah pasir, diharapkan meningkat melalui pemberian bokhasi pelepah pisang.

Penelitian bertujuan mempelajari peran bokashi pelepah pisang dalam memperbaiki sifat tanah pasir pantai bagi tanaman kedelai berdasarkan serapan hara NPK, dan mempelajari tanggapan beberapa kultivar kedelai terhadap taraf pemberian bokashi pelepah pisang dan menentukan takaran optimumnya bagi pertumbuhan dan hasil kedelai di lahan pasir pantai.

\section{BAHAN DAN METODE PENELITIAN}

Penelitian telah dilakukan di lahan pasir pantai Samas, desa Srigading, kecamatan Sanden, kabupaten Bantul, Daerah Istimewa Yogyakarta, Indonesia. Waktu penelitian selama 4 bulan, mulai Januari sampai dengan April 2017.

Percobaan pot (polibeg) dengan rancangan perlakuan faktorial $(4 \times 12)$ disusun dengan Rancangan Acak Kelompok Lengkap (RAKL), dan diulang 3 (tiga) kali. Faktor pertama yaitu dosis bokashi meliputi: 0, 20, 40, dan 60 t.ha ${ }^{-1}$ dan faktor kedua adalah kultivar kedelai yaitu Anjasmoro, Argomulyo, Burangrang, Demas 1, Dena 1, Devon 1, Gamasugen 1, Gema, Gepak ljo, Grobogan, Kaba dan Slamet. Unit percobaan terdiri dari 6 pot masing-masing 2 tanaman setiap potnya, sehingga totalnya ada 864 pot.

Pelepah pisang dicacah ukuran 3-5 cm, selanjutnya ditiriskan selama 1 minggu sebelum digunakan sebagai bahan baku bokashi. Bahan baku bokashi yang digunakan meliputi pelepah pisang (60\%), arang sekam (20\%), kotoran sapi $(10 \%)$, dedak padi (6\%) dan dolomit (4\%). Persentase bahan tersebut berdasarkan perbandingan bobot keringnya.

Pembuatan bokashi dilakukan secara aerobik dengan menggunakan efektif mikroorganisme (EM). Efektif mikroorganisme dibuat dengan cara mencampur larutan EM4 dengan molase (tetes tebu) dan air perbandingan 1 liter EM4, 1 liter molase, dan 50 liter air. Larutan tersebut dibuat minimum 2 hari (48 jam), sebelum digunakan untuk fermentasi bahan organik (Triyanto, 2016). Bahan bokashi dicampur merata menggunakan sekop, kemudian disemprot larutan EM menggunakan sprayer sambil campuran bahan tersebut diaduk-aduk. Fermentasi bokashi dilakukan dengan menginkubasi bahan pada petak ukuran $100 \mathrm{~cm} \times 80 \mathrm{~cm}$, dengan ketebalan $60 \mathrm{~cm}$, 
dengan ditutup menggunakan karung. Bokashi yang sudah jadi ditandai dengan perubahan fisik bahan yang sudah menyerupai tanah (warna kehitaman), dengan suhu yang sudah stabil mengikuti suhu ruangan.

Tanah pasir diayak menggunakan ayakan $2 \mathrm{~mm}$ untuk memisahkan seresah dan kotoran yang terbawa. Media tanah pasir ditimbang sebanyak $15 \mathrm{~kg}$ dan dimasukan polibeg. Perlakuan dosis bokashi pelepah pisang yaitu 0, 20, 40 dan 60 t.ha-1 $\left(0,90,180\right.$ dan $^{-1} 40$ g.pot $\left.^{-1}\right)$ diberikan dengan dicampur pada permukaan media tanah pasir secara merata dalam polibeg. Media disiram air dan dipertahankan pada kondisi kapasitas lapangan selama 2 hari sebelum akhirnya benih kedelai ditanam.

Pengamatan pertumbuhan meliputi serapan hara $\mathrm{N}, \mathrm{P}$ dan $\mathrm{K}$, bobot kering akar, bobot kering tajuk dan bobot kering tanaman. Data pengamatan dianalisis dengan analisis varian (ANOVA) menurut rancangan faktorial, bila berbeda nyata dilanjutkan dengan DMRT pada taraf kesalahan $5 \%$ untuk mengetahui tanggap kultivar kedelai pada pemberian bokashi pelepah pisang. Analisis korelasi dan regresi dilakukan untuk mengetahui hubungan antara variabel pengamatan, dan bentuk hubungan antara taraf perlakuan dengan bobot kering tanaman beberapa kultivar yang diuji.

\section{HASIL DAN PEMBAHASAN}

Bokashi pelepah pisang yang digunakan dalam penelitian mengandung $\mathrm{N}, \mathrm{P}$, dan $\mathrm{K}$ total sebesar 1.26; 1,69 dan $2.15 \%$. Melalui fermentasi menggunakan efective microorganism (EM), nisbah $\mathrm{C} / \mathrm{N}$ campuran bahan bokashi menurun yaitu dari semula 51.07 menjadi 13,28 setelah 42 hari (Faozi, 2018). Penggunaan bokashi pelepah pisang pada tanah pasir pantai selain bertujuan untuk meningkatkan $\mathrm{C}$ organik tanah, juga untuk meningkatkan ketersediaan hara terutama N, P dan K. Kemampuan tanah pasir dalam memegang air maupun hara diharapkan akan meningkat, demikian juga dengan serapan hara tersebut oleh tanaman.

Hasil analisis tanah pasir pantai yang digunakan pada percobaan ini disajikan pada Tabel 1. Berdasarkan hasil analisis tanah tersebut, dapat diketahui bahwa kandungan bahan organik tanah sangat rendah $(0,157 \%), \mathrm{pH} \mathrm{H}_{2} \mathrm{O}$ tergolong masam $(5,48)$ dan tekstur pasir (fraksi pasir mencapai 99,64\%) sehingga pemberian bokashi pelepah pisang dapat berperan meningkatkan kandungan bahan organik dan produktivitasnya. 
Tabel 1. Hasil analisis tanah pasir pantai di lokasi penelitian sebelum perlakuan

\begin{tabular}{|c|c|c|c|c|}
\hline Parameter & Satuan & Hasil uji & Kriteria BPT 2015 & Metode \\
\hline Karbon Organik & $\%$ & 0,091 & $<1$ sangat rendah & Walkey and Black \\
\hline Nitrogen Total & $\%$ & 0,010 & $<0,1$ sangat rendah & Kjeldahl \\
\hline $\mathrm{C} / \mathrm{N}$ ratio & & 9,10 & 5-10 rendah & Kalkulasi \\
\hline $\mathrm{pH} \mathrm{H} \mathrm{H}_{2} \mathrm{O}$ & & 5,48 & $4,5-5,5$ masam & Elektrometri \\
\hline $\mathrm{DHL}$ & uS & 25,1 & $<1000$ sangat rendah & Elektrometri \\
\hline Bahan Organik & $\%$ & 0,157 & & Konversi \\
\hline $\mathrm{P}_{2} \mathrm{O}_{5}$ total & $\%$ & 0,139 & $>0,06$ sangat tinggi & Kolorimetri \\
\hline $\mathrm{K}_{2} \mathrm{O}$ total & $\%$ & 0,005 & $<0,01$ sangat rendah & Flamefotometri \\
\hline $\mathrm{N}$ tersedia & ppm & 4,20 & 3-8 tinggi & Destilasi \\
\hline $\mathrm{P}_{2} \mathrm{O}_{5}$ tersedia & $\mathrm{ppm}$ & 59,682 & $>20$ sangat tinggi & Kolorimetri \\
\hline $\mathrm{K}_{2} \mathrm{O}$ tersedia & $\mathrm{me} \%$ & 0,263 & $0,1-0,3$ rendah & Flamefotometri \\
\hline KPK & $\mathrm{me} \%$ & 0,799 & $<5$ sangat rendah & Destilasi \\
\hline Ca-dd & $\mathrm{me} \%$ & 1,887 & $<2$ sangat rendah & AAS \\
\hline Mg-dd & $\mathrm{me} \%$ & 0,386 & $<0,4$ sangat rendah & AAS \\
\hline K-dd & $\mathrm{me} \%$ & 0,218 & $0,1-0,3$ rendah & AAS \\
\hline Na-dd & $\mathrm{me} \%$ & 0,478 & $0,4-0,7$ sedang & AAS \\
\hline Pasir & $\%$ & 99,64 & & \\
\hline Debu & $\%$ & 0,20 & & \\
\hline Lempung & $\%$ & 0,16 & & \\
\hline Tekstur & & Pasir & & Pipet \\
\hline BJ & g. $\mathrm{cm}^{-3}$ & 2,997 & & Piknometer \\
\hline BV & g. $\mathrm{cm}^{-3}$ & 1,694 & & Ring \\
\hline
\end{tabular}

Keterangan: Contoh tanah dianalisis di Laboratorium Tanah dan Sumberdaya Lahan, Fakultas Pertanian UNSOED, Purwokerto.

Berdasarkan penelitian pendahuluan, pemberian bokashi pelepah pisang dapat meningkatkan kemampuan tanah dalam memegang air, C-organik, N-total, P-total, daya hantar listrik (DHL) dan $\mathrm{pH}$ tanah. Seiring dengan lamanya waktu inkubasi bokashi hingga 8 minggu berada dalam tanah maka kemampuan memegang air, karbon organik, N-total, DHL, dan pH media tanah akan menurun (Faozi, 2018). Meningkatnya kandungan $\mathrm{N}, \mathrm{P}$ dan $\mathrm{K}$ total tanah melalui pemberian bokashi pelepah pisang diharapkan akan meningkatkan kandungan hara yang tersedia maupun diserap oleh tanaman.

Beberapa kultivar kedelai yang ditanam di tanah pasir pantai dengan pemberian bokashi pelepah pisang menunjukkan beragam antar kultivar maupun tanggapannya terhadap takaran bokashi yang diberikan baik pada serapan hara NPK maupun akumulasi bahan kering tanaman kedelai. Serapan hara N, P dan K yang dihitung berdasarkan kandungan $\mathrm{N}$-total, P-total, dan K-total jaringan daun serta bobot kering tanaman pada umur 8 minggu setelah tanam menunjukkan adanya interaksi faktor perlakuan takaran bokashi pelepah pisang dengan kultivar kedelai yang diuji. 
Tabel 2. Serapan hara $\mathrm{N}$ beberapa kultivar kedelai pada taraf pemberian bokashi pelepah pisang di tanah pasir pantai

\begin{tabular}{|c|c|c|c|c|c|}
\hline \multirow{3}{*}{ Kultivar Kedelai } & \multicolumn{5}{|c|}{ Serapan hara N $\left(\mathrm{mg}\right.$ pot $\left.^{-1}\right)$} \\
\hline & \multicolumn{5}{|c|}{ Takaran bokashi (t.ha-1) } \\
\hline & 0 & 20 & 40 & 60 & Rerata \\
\hline Anjasmoro & $70,41 \mathrm{~g}-\mathrm{i}$ & $77,44 \mathrm{fg}$ & 86,96 ef & $40,35 \mathrm{qr}$ & 68,79 \\
\hline Argomulyo & $96,49 \mathrm{e}$ & $95,06 \mathrm{e}$ & 96,23 e & $107,21 d$ & 98,75 \\
\hline Burangrang & $58,26 j-n$ & $76,18 \mathrm{fg}$ & $78,09 \mathrm{fg}$ & $73,74 \mathrm{~g}-\mathrm{i}$ & 71,57 \\
\hline Demas 1 & $130,79 \mathrm{c}$ & $212,08 a$ & $147,53 \mathrm{~b}$ & $128,51 \mathrm{c}$ & 154,73 \\
\hline Dena 1 & $54,23 m-p$ & $69,14 \mathrm{~g}-\mathrm{k}$ & $71,69 \mathrm{~g}-\mathrm{i}$ & 93,32 e & 72,09 \\
\hline Devon 1 & 57,84 j-n & 56,30 I-o & $76,24 \mathrm{fg}$ & $74,86 \mathrm{~g}-\mathrm{h}$ & 66,31 \\
\hline Gamasugen 1 & $24,79 \mathrm{~s}$ & $43,89 p-r$ & $42,01 \mathrm{p}-\mathrm{r}$ & 36,36 rs & 36,76 \\
\hline Gema & $26,11 \mathrm{~s}$ & 45,51 o-r & $48,51 \mathrm{n}-\mathrm{r}$ & $42,31 p-r$ & 40,61 \\
\hline Gepak ljo & $51,48 m-q$ & $91,48 \mathrm{e}$ & $62,86 \mathrm{~h}-\mathrm{m}$ & $61,99 \mathrm{i}-\mathrm{m}$ & 66,95 \\
\hline Grobogan & 67,16 g-I & $77,76 \mathrm{fg}$ & $95,82 \mathrm{e}$ & $125,50 \mathrm{c}$ & 91,56 \\
\hline Kaba & $40,08 \mathrm{qr}$ & $48,25 n-r$ & 57,36 k-o & $52,41 \mathrm{~m}-\mathrm{q}$ & 49,53 \\
\hline Slamet & $51,36 \mathrm{~m}-\mathrm{q}$ & $69,75 \mathrm{~g}-\mathrm{j}$ & $72,80 \mathrm{~g}-\mathrm{i}$ & $90,59 \mathrm{e}$ & 71,13 \\
\hline Rerata & 60,75 & 80,24 & 78,01 & 77,26 & $74,06(+)$ \\
\hline C.V. $=8,68 \%$ & & & & & \\
\hline
\end{tabular}

Serapan hara $\mathrm{N}$ kultivar Demas 1 yang diberi bokashi pelepah pisang takaran 20 t.ha $^{-1}$ sebesar 212,08 mg.pot ${ }^{-1}$ menunjukkan paling tinggi dibandingkan perlakuan lainnya (Tabel 2). Kultivar kedelai Anjasmoro, Burangrang, Demas 1, Devon 1, Gamasugen 1, Gema, Gepak ljo, Kaba, juga meningkat serapan hara N tanamannya dengan pemberian bokashi pelepah pisang dengan takaran 20 maupun 40 t.ha-1, dan menurun dengan pemberian bokashi pada takaran 60 t.ha-1. Adapun kultivar kedelai yang masih meningkat serapan hara $\mathrm{N}$ tanamannya dengan pemberian bokashi hingga 60 t.ha $^{-1}$ yaitu Argomulyo, Dena 1, Grobogan dan Slamet. Kultivar Gamasugen 1 dan Gema mempunyai nilai rerata serapan hara $\mathrm{N}$ tanaman yang paling kecil yaitu sebesar 36,76 dan 40,61 mg.pot ${ }^{-1}$.

Pemberian bokashi pelepah pisang secara signifikan juga meningkatkan serapan hara $\mathrm{P}$ dan $\mathrm{K}$ dari berbagai kultivar kedelai yang diuji dengan pola respon yang beragam seperti disajikan pada Tabel 3 dan Tabel 4. Serapan hara $P$ tanaman dari kultivar kedelai secara umum meningkat dengan pemberian bokashi pelepah pisang pada takaran 20 hingga 40 t.ha $^{-1}$, kecuali Kultivar Devon 1 yang masih

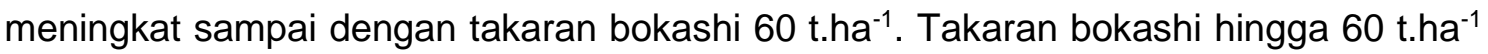
meskipun secara fisika tanah mampu meningkatkan kadar lengas tersedia, maupun kandungan $\mathrm{P}$-total tanah, namun demikian bila dilihat dari serapan hara $\mathrm{P}$ tanaman menunjukkan sudah berlebih karena jumlah unsur $P$ yang terserap justru menurun dibandingkan dengan serapan P pada takaran bokashi yang lebih rendah. 
Faozi et al., / Vegetalika. 2019. 8(3): 177-191

Tabel 4. Serapan hara $\mathrm{K}$ beberapa kultivar kedelai pada taraf pemberian bokashi pelepah pisang di tanah pasir pantai

\begin{tabular}{|c|c|c|c|c|c|}
\hline \multirow{3}{*}{ Kultivar Kedelai } & \multicolumn{5}{|c|}{ Serapan hara K (mg.pot $\left.{ }^{-1}\right)$} \\
\hline & \multicolumn{5}{|c|}{ Takaran bokashi (t.ha-1 $\left.^{-1}\right)$} \\
\hline & 0 & 20 & 40 & 60 & Rerata \\
\hline Anjasmoro & $10,79 p-s$ & $13,64 \mathrm{k}-\mathrm{o}$ & 16,09 h-k & $14,37 \mathrm{j}-\mathrm{n}$ & 13,72 \\
\hline Argomulyo & $15,97 \mathrm{~h}-\mathrm{I}$ & $22,85 \mathrm{~cd}$ & $22,21 \mathrm{~cd}$ & $34,31 \mathrm{a}$ & 23,83 \\
\hline Burangrang & 15,65 h-I & $28,07 \mathrm{~b}$ & $21,11 \mathrm{de}$ & $23,74 \mathrm{c}$ & 22,14 \\
\hline Demas 1 & $14,91 \mathrm{i}-\mathrm{m}$ & $13,08 m-q$ & $23,95 \mathrm{c}$ & 33,82 a & 21,44 \\
\hline Dena 1 & $10,76 q-s$ & $13,441-p$ & $18,70 \mathrm{fg}$ & $22,14 \mathrm{~cd}$ & 16,26 \\
\hline Devon 1 & $10,54 \mathrm{q}-\mathrm{s}$ & 11,03 o-s & $12,71 \mathrm{~m}-\mathrm{q}$ & $16,60 \mathrm{~g}-\mathrm{j}$ & 12,72 \\
\hline Gamasugen 1 & $5,53 \mathrm{u}$ & 7,53 tu & $11,84 n-r$ & $7,20 \mathrm{tu}$ & 8,03 \\
\hline Gema & $9,72 r-t$ & $18,05 \mathrm{f}-\mathrm{h}$ & 19,21 ef & $12,50 \mathrm{~m}-\mathrm{q}$ & 14,87 \\
\hline Gepak ljo & 8,73 st & $10,73 q-s$ & $13,58 \mathrm{k}-\mathrm{o}$ & $10,91 \mathrm{p}-\mathrm{s}$ & 10,99 \\
\hline Grobogan & $12,39 \mathrm{~m}-\mathrm{q}$ & $34,56 \mathrm{a}$ & $24,18 \mathrm{c}$ & $23,93 \mathrm{c}$ & 23,76 \\
\hline Kaba & $5,34 \mathrm{u}$ & $9,51 \mathrm{r}-\mathrm{t}$ & $12,89 \mathrm{~m}-\mathrm{q}$ & $8,54 \mathrm{st}$ & 9,07 \\
\hline Slamet & 11,14 o-s & 16,16 h-k & 15,77 h-I & $17,44 \mathrm{f}-\mathrm{i}$ & 15,13 \\
\hline Rerata & 10,96 & 16,55 & 17,69 & 18,79 & $16,00(+)$ \\
\hline \multicolumn{6}{|l|}{ C.V. $=9,28 \%$} \\
\hline $\begin{array}{l}\text { Gand } \\
\text { kultiv }\end{array}$ & yata. & 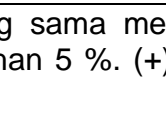 & & p & $\begin{array}{l}\text { Uji Jarak } \\
\text { isang dan }\end{array}$ \\
\hline
\end{tabular}

Bobot kering tanaman (akar dan tajuk) yang diamati saat tanaman dipanen dari berbagai kultivar kedelai pada taraf pemberian bokashi pelepah pisang disajikan pada Tabel 5. Berbagai kultivar kedelai yang diuji tanggap terhadap pemberian bokashi pelepah pisang, dan menunjukkan adanya interaksi antara faktor perlakuan takaran bokashi dengan kultivar kedelai. Kultivar kedelai yang diuji meningkat bobot kering tanamannya dengan pemberian bokashi pelepah pisang dengan peningkatan paling tinggi pada takaran bokashi 20 t.ha $^{-1}$ maupun 40 t.ha-1. Berdasarkan reratanya $(33,69$ g. pot $\left.^{-1}\right)$, kultivar kedelai yang mempunyai ukuran bobot kering tanaman paling besar yaitu Demas 1 (66,30 g.pot $\left.{ }^{-1}\right)$, diikuti Slamet (40,33 g.pot $\left.{ }^{-1}\right)$, Argomulyo (40,14 g.pot $\left.{ }^{-1}\right)$, Anjasmoro (37,99 g.pot $\left.{ }^{-1}\right)$, dan Dena 1 (36,84 g.pot $\left.{ }^{-1}\right)$. Kultivar Gema dan Gamasugen 1 mempunyai bobot kering tanaman paling kecil yaitu 11,20 dan 15,62 g.pot ${ }^{-1}$. Adapun tanggapan kultivar kedelai secara umum meningkat bobot kering tanamannya dengan pemberian bokashi mulai takaran 20 t.ha $^{-1}$, dan pada pemberian bokashi yang lebih tinggi lagi yaitu pada takaran 40 hingga 60 t.ha $^{-1}$ tanggapannya ada yang masih meningkat, juga ada yang tidak meningkat lagi atau malah menurun bobot kering tanamannya. 
Tabel 5. Bobot kering tanaman beberapa kultivar kedelai pada taraf pemberian bokashi pelepah pisang di tanah pasir pantai

\begin{tabular}{|c|c|c|c|c|c|}
\hline \multirow{3}{*}{ Kultivar Kedelai } & \multicolumn{5}{|c|}{ Bobot kering tanaman $\left(\mathrm{g} \cdot \mathrm{pot}^{-1}\right)$} \\
\hline & \multicolumn{5}{|c|}{ Takaran bokashi $\left(\right.$ t.ha $\left.^{-1}\right)$} \\
\hline & 0 & 20 & 40 & 60 & Rerata \\
\hline Anjasmoro & $33,93 \mathrm{~h}-0$ & $42,24 \mathrm{e}-\mathrm{g}$ & 39,36 e-i & $36,44 \mathrm{f}-\mathrm{m}$ & 37,99 \\
\hline Argomulyo & $35,38 \mathrm{f}-\mathrm{m}$ & $44,74 d-e$ & 42,79 ef & $37,63 \mathrm{e}-\mathrm{I}$ & 40,14 \\
\hline Burangrang & $27,11 n-p$ & 30,93 j-p & 31,27 h-p & $34,52 \mathrm{~g}-\mathrm{n}$ & 30,96 \\
\hline Demas 1 & $55,70 \mathrm{c}$ & $73,85 a$ & $69,17 a b$ & $66,50 \mathrm{~b}$ & 66,30 \\
\hline Dena 1 & $34,46 \mathrm{~g}-\mathrm{n}$ & 38,78 e-j & $37,92 \mathrm{e}-\mathrm{k}$ & $36,21 \mathrm{f}-\mathrm{m}$ & 36,84 \\
\hline Devon 1 & $23,57 p-q$ & 25,64 op & $30,921-p$ & $32,58 \mathrm{i}-0$ & 28,43 \\
\hline Gamasugen 1 & $10,83 r$ & $11,82 r$ & $11,14 r$ & $11,00 \mathrm{r}$ & 11,20 \\
\hline Gema & $15,51 \mathrm{r}$ & $16,95 \mathrm{qr}$ & $15,63 \mathrm{r}$ & $14,40 r$ & 15,62 \\
\hline Gepak ljo & 25,76 op & $29,06 m-p$ & 38,83 e-j & 36,71 e-m & 32,59 \\
\hline Grobogan & $23,56 \mathrm{pq}$ & 33,56 h-o & 33,34 h-o & 39,65 e-h & 32,53 \\
\hline Kaba & $27,53 n-p$ & $31,05 \mathrm{i}-\mathrm{p}$ & 33,12 h-o & 33,88 h-n & 31,40 \\
\hline Slamet & 30,29 k-p & 31,73 h-p & $50,47 \mathrm{~cd}$ & $48,83 d$ & 40,33 \\
\hline Rerata & 28,64 & 34,20 & 36,14 & 35,80 & $33,69(+)$ \\
\hline C.V. $=10,02 \%$ & & & & & \\
\hline
\end{tabular}

Hasil biji tertinggi yaitu pada Kultivar Demas 1 yang diberi bokashi pelepah pisang takaran 20 t.ha $^{-1}$ yaitu sebesar 59,03 g. pot $^{-1}$, diikuti hasil biji dari Kultivar Demas 1 juga pada pemberian bokashi takaran 40; 60; dan 0 t.ha-1 berturut-turut 51,$11 ; 47,11$; dan 38,72 g. pot $^{-1}$. Berdasarkan Tabel 6, kultivar kedelai yang mempunyai hasil biji lebih rendah di bawah hasil biji Kultivar Demas 1 adalah Argomulyo, Gepak ljo dan Anjasmoro. Adapun kultivar kedelai yang mempunyai hasil biji paling rendah adalah Gema dan Gamasugen 1 dengan rerata hasil bijinya sebesar 7,64 dan 7,82 g.pot ${ }^{-1}$. Berdasarkan hasil bijinya dapat diketahui kultivar yang tanggap atau tidak tanggap terhadap pemberian bokashi, maupun yang berdaya hasil tinggi maupun rendah.

Korelasi antara bobot kering tanaman, serapan hara NPK dan bobot biji kedelai dengan pemberian bokashi pelepah pisang disajikan pada Tabel 7. Bobot kering tanaman berkorelasi positif dengan serapan $\mathrm{N}$, serapan $\mathrm{K}$ dan bobot biji kedelai yaitu dengan nilai koefisien korelasi $r=0,822^{* *}$ (serapan $N$ ), $r=0,420^{*}$ (serapan $K$ ), dan $r=$ $0,856^{* *}$ (bobot biji). Serapan $N$ tanaman berkorelasi positif dengan serapan $\mathrm{K}(r=$ $\left.0,511^{*}\right)$, dan bobot biji kedelai $\left(r=0,777^{\star *}\right)$. Serapan $N$ dan $P$ tanaman berkorelasi dengan serapan $\mathrm{K}$, tetapi serapan $\mathrm{K}$ tidak berkorelasi dengan bobot biji kedelai yang dihasilkan. 
Tabel 6. Hasil biji beberapa kultivar kedelai pada taraf pemberian bokashi pelepah pisang

\begin{tabular}{|c|c|c|c|c|c|}
\hline \multirow{3}{*}{ Kultivar Kedelai } & \multicolumn{5}{|c|}{ Hasil biji (g.pot $\left.{ }^{-1}\right)$} \\
\hline & \multicolumn{5}{|c|}{ Takaran bokashi (t.ha $\left.{ }^{-1}\right)$} \\
\hline & 0 & 20 & 40 & 60 & Rerata \\
\hline Anjasmoro & $14,55 \mathrm{I}-\mathrm{p}$ & $28,22 d-g$ & $28,96 \mathrm{~d}-\mathrm{f}$ & $24,23 d-j$ & 23,99 \\
\hline Argomulyo & 21,84 e-I & $31,82 \mathrm{~d}$ & 29,65 de & 29,25 de & 28,14 \\
\hline Burangrang & 12,06 n-p & $11,83 n-p$ & $11,34 n-p$ & $10,94 n-p$ & 11,54 \\
\hline Demas 1 & $38,72 \mathrm{c}$ & $59,03 \mathrm{a}$ & $51,11 \mathrm{~b}$ & $47,11 \mathrm{~b}$ & 48,99 \\
\hline Dena 1 & 21,46 e-l & $20,73 \mathrm{f}-\mathrm{m}$ & 19,30 h-n & $17,95 \mathrm{i}-\mathrm{n}$ & 19,86 \\
\hline Devon 1 & 11,96 n-p & $12,97 \mathrm{~m}-\mathrm{p}$ & 15,49 k-p & $12,12 n-p$ & 13,13 \\
\hline Gamasugen 1 & 8,78 op & $7,58 p$ & $7,49 p$ & $7,45 p$ & 7,82 \\
\hline Gema & $7,73 p$ & $7,70 \mathrm{p}$ & $7,69 \mathrm{p}$ & $7,44 \mathrm{p}$ & 7,64 \\
\hline Gepak ljo & $23,54 \mathrm{~d}-\mathrm{k}$ & $26,31 d-h$ & $26,99 \mathrm{~d}-\mathrm{h}$ & $25,88 d-i$ & 25,68 \\
\hline Grobogan & $20,63 \mathrm{~g}-\mathrm{m}$ & $17,86 \mathrm{i}-\mathrm{n}$ & $17,77 \mathrm{i}-\mathrm{n}$ & $17,01 \mathrm{j}-0$ & 18,32 \\
\hline Kaba & 15,38 k-p & 16,63 j-o & 16,74 j-o & 15,36 k-p & 16,03 \\
\hline Slamet & 14,59 I-p & $21,41 \mathrm{e}-\mathrm{I}$ & 27,52 d-h & $27,83 d-g$ & 22,84 \\
\hline Rerata & 17,60 & 21,84 & 21,62 & 20,27 & $20,33(+)$ \\
\hline
\end{tabular}

C.V. $=18,85 \%$

Keterangan: Angka yang diikuti huruf yang sama menunjukkan tidak berbeda nyata pada Uji Jarak Ganda Duncan tingkat kesalahan $5 \%$. (+): interaksi takaran bokashi pelepah pisang dan kultivar kedelai nyata.

Tabel 7. Korelasi antara bobot kering tanaman, serapan hara NPK, dan bobot biji berbagai kultivar kedelai pada taraf pemberian bokashi pelepah pisang

\begin{tabular}{lccccc}
\hline Komponen & BK Tanaman & Serapan N & Serapan P & Serapan K & Bobot Biji \\
\hline BK Tanaman & 1,000 & $0,822^{* *}$ & $0,180^{\text {tn }}$ & $0,420^{*}$ & $0,856^{* *}$ \\
Serapan N & 1,000 & $0,305^{\text {tn }}$ & $0,511^{*}$ & $0,777^{\star *}$ \\
Serapan P & & 1,000 & $0,543^{*}$ & $0,080^{\text {tn }}$ \\
Serapan K & & & 1,000 & $0,286^{\text {tn }}$ \\
Bobot Biji & & & & 1,000 \\
\hline Keterangan: ${ }^{* *}$ ) korelasi berbeda nyata pada taraf uji $\left.1 \%,{ }^{*}\right)$ korelasi berbeda nyata pada taraf \\
uji $5 \%$, dan tn) korelasi tidak berbeda nyata pada taraf uji $5 \%$.
\end{tabular}

Tanah pasir pantai merupakan tanah marginal dengan kandungan fraksi pasir $>90 \%$, sehingga strukturnya lepas dengan porositas yang tinggi. Guna menunjang keberhasilan budidaya tanaman di lahan pasir pantai perlu dilakukan upaya konservasi lengas tanah melalui rekayasa lingkungan (Sudaryono, 2005). Pemberian bokashi pelepah pisang selain untuk meningkatkan kemampuan tanah pasir dalam menyimpan air dan hara, juga bertujuan untuk menambah ketersediaan hara bagi tanaman. Kandungan unsur hara N, P dan K total dalam bokashi sebesar 1,16; 1,69; dan 2,15\%. Melalui dekomposisi secara bertahap selama masa pertumbuhan tanaman, unsurunsur tersebut akan tersedia dan dapat dimanfaatkan oleh tanaman.

Berbagai kultivar kedelai mempunyai kemampuan adaptasi yang berbeda pada lingkungan tumbuh media tanah pasir, dengan kondisi iklim mikro di lahan pesisir pantai. Berdasarkan data serapan hara N, P, K, bobot kering tanaman dan hasil bijinya menunjukkan adanya tanggapan yang beragam terhadap takaran bokashi pelepah pisang yang diberikan. Kultivar Anjasmoro, Agromulyo, Demas 1 dan Slamet termasuk 
tanggap terhadap pemberian bokashi pelepah pisang dan dan tanggapannya bersifat kuadratik. Pemberian bokashi sampai takaran optimum dapat meningkatkan serapan hara N, P, K, bobot kering tanaman dan hasil bijinya. Menurut Utami et al. (2010), pemberian pupuk organik pada tanaman padi akan meningkatkan $\mathrm{pH}$ tanah, $\mathrm{KPK}$, dan ketersediaan hara $\mathrm{N}, \mathrm{P}$, dan $\mathrm{K}$ tanah, sehingga meningkatkan serapan hara $\mathrm{N}, \mathrm{P}, \mathrm{K}$, dan hasil tanaman. Penambahan pembenah tanah berupa bahan organik berpotensi meningkatkan hasil tanaman, mengurangi penggunaan pupuk anorganik dan memperbaiki kondisi tanah pertanian (Bass et al., 2016), dan meningkatkan serapan hara N, P, K pada tanaman jagung manis (Maftu'ah et al., 2013).

Kultivar Demas 1 yang mampu menghasilkan bobot kering tanaman maupun biji yang tinggi, dan juga tanggap terhadap pemberian bokashi pelepah pisang yaitu meningkatkan serapan $\mathrm{N}, \mathrm{P}$, dan $\mathrm{K}$ dengan pemberian bokashi takaran 20-40 t.ha ${ }^{-1}$. Serapan hara $\mathrm{N}$ tanaman maupun bahan kering tanaman justru menurun pada takaran bokashi yang mencapai 60 t.ha $^{-1}$. Bokashi pelepah pisang merupakan sumber bahan organik yang dapat memperbaiki sifat fisik tanah pasir pantai, sehingga dapat meningkatkan kemampuan tanah menyimpan air dan hara (Mustofa et al., 2012). Pemberian bokashi mencapai 60 t.ha $^{-1}$ ternyata sudah berlebihan, sehingga menyebabkan adanya kompetisi antara mikroba pengurai dengan akar tanaman dalam penggunaan oksigen maupun nitrogen.

Beberapa kultivar kedelai mempunyai nilai serapan hara yang lebih kurang sama, atau bahkan masih terus meningkat hingga takaran 60 t.ha $^{-1}$. Kultivar kedelai yang tidak tanggap pada pemberian bokashi dengan tingkat serapan hara yang lebih kurang sama dengan tanpa bokashi, tetapi ada juga yang meningkat hanya pada takaran 20 t.ha $^{-1}$, dan tidak meningkat lagi pada takaran yang lebih tinggi. Tanggapan tanaman berdasarkan serapan hara $\mathrm{N}, \mathrm{P}, \mathrm{K}$, bobot kering tanaman dan hasil biji kedelai, juga menunjukkan kesesuaian kultivar tersebut untuk dikembangkan di lahan pasir pantai. Tanggap kultivar kedelai beragam terhadap takaran bokashi yang diberikan. Secara umum kultivar kedelai meningkat pertumbuhan dan hasil bijinya pada pemberian bokashi sampai dengan takaran optimum, dan tidak meningkat lagi dengan takaran yang lebih tinggi. Namun demikian, ada juga kultivar kedelai yang tidak tanggap atau malah tertekan pertumbuhan dan hasil bijinya bila diberi bokashi pelepah pisang (Faozi et al., 2018).

Serapan hara $\mathrm{N}$ dan $\mathrm{P}$ yang tinggi akan meningkatkan serapan hara $\mathrm{K}$, bobot kering tanaman dan hasil biji kedelai. Bokashi pelepah pisang merupakan sumber $\mathrm{K}$ yang baik karena kandungan $\mathrm{K}$ total dalam bahan tersebut mencapai $2,15 \%$. Tanaman 
kedelai mampu menyerap $\mathrm{K}$ dalam jumlah tinggi, dan semakin meningkat dengan semakin banyak bokashi yang digunakan. Namun, mengingat unsur $\mathrm{K}$ bukan merupakan bagian dari struktur tanaman (Marschner, 1986) menjadi tidak berpegaruh terhadap meningkat bobot kering tanaman maupun hasil bijinya.

Berdasarkan analisis regresi data hasil biji, diperoleh kurva respon kultivar kedelai terhadap takaran pemberian bokashi pelepah pisang yang bersifat kuadratik yaitu Anjasmoro ( $\left.R^{2}=0,979\right)$; Argomulyo $\left(R^{2}=0,829\right)$; Demas $1\left(R^{2}=0,759\right)$; Devon 1 $\left(R^{2}=0,656\right)$; Gepak ljo $\left(R^{2}=0,998\right) ;$ Kaba $\left(R^{2}=0,996\right)$; dan Slamet $\left(R^{2}=0,989\right)$. Kurva respon kultivar kedelai Burangrang $\left(R^{2}=0,982\right)$; Dena $1\left(R^{2}=0,983\right)$; Gamasugen 1 $\left(R^{2}=0,676\right)$; Gema $\left(R^{2}=0,725\right)$; dan Grobogan $\left(R^{2}=0,791\right)$ bersifat linier, menurun hasil bijinya dengan pemberian bokashi pelepah pisang. Kurva respon rerata hasil biji 12 kultivar yang dicoba ditanam di lahan pasir pantai dengan taraf pemberian bokashi pelepah pisang bersifat kuadratik dengan persamaan garis regresi Yrerata $=-0,0035 x^{2}$ $+0,2505 x+17.761\left(R^{2}=0,995\right)$, diperoleh takaran bokashi optimum sebanyak 35,80 t.ha ${ }^{-1}$ dengan hasil biji maksimum 22,24 g. .ot $^{-1}$.

\section{KESIMPULAN}

1. Bokashi pelepah pisang dapat digunakan sebagai pembenah tanah pasir pantai, sekaligus sebagai penyedia unsur hara bagi pertumbuhan tanaman kedelai.

2. Tanggapan kultivar kedelai beragam menurut taraf pemberian bokashi pelepah pisang. Serapan hara N, P, K, bobot kering tanaman dan hasil biji kultivar Anjasmoro, Argomulyo, Demas 1, Devon 1, Gepak ljo, Kaba dan Slamet meningkat dengan pemberian bokashi pelepah pisang pada takaran 20 dan 40 t.ha $^{-1}$, dan menurun pada takaran bokashi mencapai 60 t.ha ${ }^{-1}$.

3. Dosis optimum takaran bokashi pelepah pisang setara 35,80 t.ha-1 $^{-1}$ dengan hasil biji maksimum 22,24 g.pot ${ }^{-1}$.

\section{DAFTAR PUSTAKA}

Adie, M.M., A. Krisnawati and D. Harnowo. 2015. Keragaman dan pengelompokan galur harapan kedelai di Kabupaten Sleman, Yogyakarta. Prosiding Seminar Nasional Masyarakat Biodiversitas Indonesia 1 (4): 787-791. 
Bass, A. M., M. I. Bird, G. Kay and B. Muirhead. 2016. Soil properties, greenhouse gas emissions and crop yield under compost, biochar, and co-composted biochar in two tropical agronomic systems. Science of the Total Environment 550: 459470.

Elnour, M. E. M., , A. G. Elfadil, , F. A. Manal and B. A. E. Saeed. 2015. Effects of banana compost on growth, development and productivity of Sorghum bicolor cultivar (Tabat). Journal of Advances In Biology 8 (2) : 1554-1561.

Faozi, K. 2018. Pertumbuhan dan Hasil Kedelai pada Pemberian Bokashi Pelepah Pisang dan Pupuk Fosfor di Lahan Pasir Pantai. Disertasi. Fakultas Pertanian, Universitas Gadjah Mada, Yogyakarta. 264p.

Faozi, K., P. Yudono, D. Indradewa and A. Ma'as. 2018. Banana stem bokashi and its effect to increase soybean yield (Glycine max L. Merrill) in coastal sands area. Journal of Agrotecnology 7 (2) DOI: 10.4172/2168-9881.1000184.

Hall, D. J. M., and R. W. Bell. 2015. Biochar and compost increase crop yields but the effect is short term on sandplain soils of Western Australia. Pedosphere 25(5): 720-728.

Hani, A. 2015. Produktivitas kedelai pada pola agroforestri nyamplung (Callophylum inophylum) di lahan pantai berpasir Pangandaran, Jawa Barat. Jurnal Silvikultur Tropika 06 (2): 78-82.

Iskak, P., J. Paris and Y. Retnowati. 2015. Uji kualitas bokhasi yang berbahan dasar pelepah tanaman pisang (Musa sp.). Laporan Penelitian. Jurusan Biologi Fakultas Matematika dan IPA Universitas negeri Gorontalo.

Jati, R.I., Tohari \& P. Suryanto. 2017. The optimum dose of nitrogen, phosporus, and potassium to improve soybean (Glycine $\max (\mathrm{L})$ Merr) productivity on kayu putih (Melaleuca cajuputi) stands. Ilmu Pertanian (Agricultural Science)2 (2): 56-63.

Kementan, 2014. Outlook komoditi pisang. Pusat Data dan Sistem Informasi Pertanian, Sekretariat Jenderal Kementerian Pertanian, Jakarta. 74p.

Kementan, 2016. Produksi pisang menurut Provinsi, 2011-2015. www.pertanian.go.id/Data5tahun/HortiASEM2015/Produksi\%20Pisang.pdf. (online) diakses tanggal 14 Mei 2016.

Kusumawati, A. 2015. Analisa karakteristik pupuk kompos berbahan batang pisang. Prosiding Seminar Nasional Universitas PGRI Yogyakarta 2015, pp: 322-328. Universitas PGRI, Yogyakarta.

Maftu'ah, E., A. Maas, A. Syukur and B. H. Purwanto. 2013. Efektivitas amelioran pada lahan gambut terdegradasi untuk meningkatkan pertumbuhan dan serapan NPK tanaman jagung manis (Zea mays L. var. saccharata). Jurnal Agronomi Indonesia $41(1): 16-23$.

Marschner, H. 1986. Mineral nutrition of higher plant. Institute of Plant Nutrition. University of Hohenheim. Federal Republic of Germany.674p.

Munadjim. 1983. Teknologi pengolahan pisang. PT. Gramedia, Jakarta. 68p.

Mustofa, W. S., M. Izzati and E. Saptiningsih. 2012. interaksi antara pembenah tanah dari Hydrilla verticillata Royle. dan Salvinia molesta Mitchell. terhadap kapasitas lapang tanah pasir dan tanah liat serta pertumbuhan kacang hijau (Vigna radiata L.) Buletin Anatomi dan Fisiologi XX (2) : 51-60. 
Okelana, M. A. O. 2001. Chemical properties and potential utilization of banana pseudostem. ASSET Series A 1 (1): 63-70

Partoyo. 2005. Analisis indeks kualitas tanah pertanian di lahan pasir pantai samas Yogyakarta. Ilmu Pertanian 12 (2): 140-151.

Purwaningsih, S. 2015. Pengaruh inokulasi rhizobium terhadap pertumbuhan tanaman kedelai (Glycine max L.) kultivar wilis di rumah kaca. Berita Biologi 14(1) : 6976.

Salvagiotti, F., K.G. Cassman, J.E. Specht, D.T. Walters, A. Weiss and A. Dobermann. 2008. Nitrogen uptake, fixation and response to fertilizer $N$ in soybeans: $A$ review. Field Crops Research 108 (2008) 1-13.

Sudaryono. 2005. Konservasi lengas tanah melalui rekayasa lingkungan pada lahan pasir beririgasi teknis di Pantai Bugel Kabupaten Kulon Progo. Jurnal Teknik Lingkungan P3TL-BPPT 6 (2): 334-351.

Syukur A. and E.S. Harsono. 2008. Pengaruh pemberian pupuk kandang dan NPK terhadap beberapa kimia dan fisika tanah pasir samas, Bantul. Jurnal IImu Tanah dan Lingkungan 8 (2): 138-145.

Triyanto. 2016. Panduan membuat pupuk bokashi dari jerami padi. https://kabartani.com/panduan-membuat-pupuk-bokashi-dari-jerami-padi.html. Online. Diakses tanggal 6 Mei 2016.

Utami, S.N.H, M. Haji and N.W. Yuwono. 2010. Serapan hara N, P, K pada tanaman padi dengan berbagai lama penggunaan pupuk organik pada vertisol Sragen. Jurnal Ilmu Tanah dan Lingkungan 10 (1) : 1-13.

Wina, E. 2001. Tanaman pisang sebagai pakan ternak ruminansia. Wartazoa 11 (1) : 20-27. 